\title{
"QUEER" KOTIUTUI: MITÄ TAPAHTUI "PERVOLLE"?
}

\author{
Leena-Maija Rossi ja Tiia Sudenkaarne
}

Suomalainen sukupuolen ja seksuaalisuuden normikriittinen tutkimus on hakenut käyttöönsä lainakäsitteitä ja lanseerannut käsiteinnovaatioita jo vuosikymmenien ajan (ks. esim. Kekki 2006; Vänskä 2006; Aldrin Salskov, Taavetti \& Rossi 2019). Sama pätee sukupuoli- ja seksuaalipoliittiseen aktivismiin, jossa on liikuttu keskustelukerho Psyke ry:n päivistä ja 50 vuotta sitten toteutuneesta dekriminalisoinnista politiikkaan, joka pyrkii edistämään sateenkaarisuhteiden yhä selkeämpää tunnistamista ja tunnustamista (Lahti ym. 2020). Käsitteet ovat toisiinsa monella tapaa kietoutuvan tutkimuksen ja politiikan perusta: asioita on nimettävä, jotta niistä voidaan keskustella, jotta niiden merkityksistä voidaan kamppailla, ja jotta niitä voidaan ajaa. Ne kantavat mukanaan kamppailun ja ajattelun historiaa, joka ei aukea samanlaisena ajasta ja paikasta riippumatta.

\section{Pervon radikaali haltuunotto}

Queer on sekä tutkimuskäsitteenä, poliittisena asenteena että identiteettimääreenä ollut harvinaisen hankala suomentumaan. Kun queer-tutkimuksellinen keskustelu 1990-luvun alkuvuosina pääsi käyntiin, käytettiin mieluusti lainasanaa (esim. Juvonen 1993). Pikkuhiljaa alkoi kuitenkin ilmaantua suomenkielisiä käännösehdotuksia - pervo, kyseenalainen, vikuuri, kumma, vino, outo, kiero - ja niihin kytkeytyviä verbimuotoja pervouttamisesta outouttamiseen ja vikurointiin. Tutkijat ryhtyivät käyttämään suomennoksia rinnakkain myös laina-queerin kanssa, moni omassakin käytössään vaihdellen.

Vuonna 2006 Lasse Kekki (1964-2006), yksi suomalaisen queer-tutkimuksen uranuurtajista, julkaisi Kulttuurintutkimus-lehdessä artikkelin "Pervon puolustus". Kekki, joka kuului Turun yliopiston queer-tutkimuksen kantaviin voimiin, oli myös yksi Pervot päivät-tutkimusseminaarin alullepanijoista ja pervo-termin uutterista käyttäjistä queerin suomennoksena. Kekin perusteet pervon eduista tutkimusterminä olivat tinkimättömät. Siinä, missä queerille oli ehdoteltu monenlaisia muita käännöksiä kummasta ja kummastelusta kieroon ja kierouttamiseen, pervo oli Kekin mukaan lopulta ainoa, joka sisällytti itseensä selkeästi seksuaalisuuden, ja nimenomaan normatiivisesti katsoen "vääränlaisen" seksuaalisuuden konnotaation. Hän kirjoitti: "Väitän, että jos luovumme queer-käsitteen suomennoksessa uhkaavuutta korostavasta pervouden dimensiosta, queerin suomennos ja merkitys vapautuvat helposti, vaikka eivät välttämättä, konservatiivisen ja heteronormatiivisen politiikan välineiksi." (Kekki 2006, 4.) Kekki painotti, 2000-luvun alun tapaan, pervon puolustuksessaan juuri seksuaalisuuden ulottuvuutta ja arvioi transsukupuolisuuden (samoin kuin biseksuaalisuuden) jääneen queer-tutkimuksessa taka-alalle. Voidaan kuitenkin hyvin perustein väittää, että suomen kielen pervo-sana on kattanut historiallisesti myös sukupuolen suhteen epänormatiiviset subjektit.
Pervo

peruutuspeili

Puheenvuoro

. 
Pervoa onkin käytetty häpeilemättömästi tutkimuksen terminä, juuri sen häpäisyhistorian vuoksi. Samaan tapaan kuin englannin kielen queer, pervo on toiminut pitkään pejoratiivisena, loukkaavaksi tarkoitettuna ja leimaavana adjektiivina tai substantiivina. Mutta toisin kuin queer, joka on (suomeksikin) selkeästi otettu itsemäärittelyn välineeksi, ja jolla on angloamerikkalaisessa kulttuurissa ollut kiistatta kosolti kumouksellista poliittista voimaa, pervon tutkimus- ja aktivistinen käyttö - Lasse Kekkiä lainaten "radikaali haltuunotto" $(2006,9)$ ei ole toteutunut suomenkielisessä ympäristössä samalla tavoin. Osa queer-yhteisöä on kaihtanut pervon performatiivista toisin toistamista ja pitäytynyt muissa suomennoksissa tai queer-lainasanan käytössä. Viime vuosina tutkijayhteisössä on myös keskusteltu siitä, että jotkut kokevat pervon henkilökohtaisesti loukkaavaksi. Paradoksaalisesti tämä pitää varmasti paikkansa, sillä affektiivinen vaikuttavuus on yksi käsitteiden voimista. Samaan aikaan on kuitenkin pohdittava, menetetäänkö nimenomaan suomenkielisen käsitteen epämukavuudesta luovuttaessa jotakin paikantuneesti merkittävää.

Siinä missä queer on nimenomaan istunut itsemäärittelyn välineeksi, voinee sanoa, että pervo on siis toiminut sellaisena hennommin. Toki pervon ilkikurista viljelyä on harrastettu etenkin homokulttuurissa "sumeilematta", kuten Kekki jo viisitoista vuotta sitten totesi: "Pervo onkin iskevä, merkitykseltään ambivalentti, sekä käyttäjästään että käyttötilanteestaan riippuva sana, jonka leviäminen sekä puhekieleen että tieteen kieleen on yksi viime vuosien seksuaalidiskurssien kiintoisista piirteistä.” $(2006,3$.) 2020-luvun kiikkerässä internet-kaikupohjaisessa keskustelukulttuurissa, jota ovat ratkaisevalla tavalla globaalisti muokanneet Yhdysvalloista liikkeelle lähteneet poliittiset linjat ja trendit, ollaan kuitenkin aiempaa varovaisempia erilaisten pejoratiivislähtöisten termien kanssa. Monikaan aktivisti ja queer-identifioituva ei ylpeästi tunnustaudu pervoksi. Vaikuttaa siltä, että nykyisin pervo tuottaa juopaa tutkimus- ja aktivistikenttien välille, ja jopa sisällekin. Taustalla voi olla myös yhdysvaltalaisen populaarikulttuurin ja tutkimuskäsitteistön ylivalta: suomalaisia sukupuolen ja seksuaalisuuden moninaisuuden historiallis-kulttuurisia narratiiveja tunnetaan täällä huonommin kuin yhdysvaltalaisia, mitä voi pitää huolestuttavana.

\section{Pervon paikka?}

Tuntuu myös siltä, että harvat ovat tietoisia perversion freudilaisesta merkityspotentiaalista: siitä, että vietti ylipäänsä olisi luontoa vastaan, eikä inhimillinen seksuaalisuus siten olisi "luonnollista" (Kekki 2006, 6). Juuri tuo freudilainen kaiken seksuaalisuuden queeriyttäminen, jos lainasanaa käytetään, tuntuu edelleen olevan sen ytimessä, mitä myös pervo-termin tutkimuskäytöllä haluttiin tehdä, ja missä eittämättä myös onnistuttiin. Tästä todistavat esimerkiksi pervo-tutkimustapahtumien jatkumo ja pervo-termin vakiintuminen suomalaisen queer-tutkimuksen julkaisun SQS-lehden sisällön rakenteessa ("Pervoskooppi": vertaisarvioidut artikkelit,"Pervopeili": katsausartikkelit, "Pervo/peruutus/peili": keskustelua, "Pervolinssi": taidegalleria ja "Pervosilmäys": arvioita) - ja "pervon" pysyminen ylipäänsä sitkeästi tutkimuskäytössä. Tämä omaleimainen käsitehistoria ansaitsee tulla tunnustetuksi laajemmin. Myös sen hyvää paikallista perintöä pitää pyrkiä vaalimaan osana suomalaisen queer-tutkimuksen kehitystä. Niin ikään pervon haltuunotto myös sukupuolen kaikinpuolisessa outouttamisessa ja epäluonnollistamisessa olisi perusteltua.

Suomen Queer-tutkimuksen Seuran hallitus päätti syksyllä 2021 alkaa kutsua Pervo tutkimusteko -palkintoa queer-tutkimustekopalkinnoksi. Pohdinnassa on myös Pervot päivät -tutkimusseminaarin brändääminen puhtaasti yleiseksi queer-tutkimusseminaariksi. Syy muutoksiin on ollut queer-yhteisön sisältä tullut viesti siitä, että "pervo" koetaan osin ulossulkevaksi ja epämiellyttäväksi. Onkin totta, että sukupuolen moninaisuuden ulottuvuus ei juuri korostu käsitteen käytön perusteluja tarkasteltaessa. Tosin pejoratiivisessa merkityksessään "pervo" on ehdottomasti viitannut

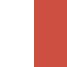


sekä seksuaalisuuden että sukupuolen moninaisuuteen. Myös perversion käsitehistoriaa sekä sukupuolen ja seksuaalisuuden moninaisuuden diagnostista määrittelyä seuraamalla hahmottuu, että sukupuolen ja seksuaalisuuden sfärien erottaminen toisistaan on verraten nuori ilmiö (Drescher 2010; Parhi \& Sudenkaarne 2021). Queer-yhteisön itsemäärittely voi tietenkin olla, ja onkin, tällaisille kontrollidiskursseille vastakkaista. Nähdäksemme on kuitenkin kriittisesti pohdittava, miksi juuri pervon olisi palattava kaappiin vai voisiko se jatkaa eloaan queerin kumppanina.

Suomalaisen queer-tutkimuksen tulisi myös kriittisesti tarkastella, onko queerin merkitys vapautunut konservatiivisen ja heteronormatiivisen politiikan välineiksi Kekin (2006) esittämällä tavalla. Ainakin on perusteltua puhua homonormatiivisuuden noususta heteronormatiivisuuden rinnalle. Viime vuosikymmenien suuret yhteiskunnalliset sukupuolen ja seksuaalisuuden moninaisuuden suomalaiset keskustelut ovat kytkeytyneet perinteisten instituutioiden kuten avioliiton ja perheen avautumiseen queer-ihmisille. (Lahti ym. 2020.) On kuitenkin syytä huomata, että seksuaalisuuden tarkastelu uhkaa edelleen ylikorostua sukupuolen kustannuksella: esimerkiksi avioliittolainsäädäntöä on ollut näennäisesti helpompi muuttaa kuin sukupuolen juridisen korjaamisen eugeniikasta ammentavia perusteita. Kamppailut ovat tietenkin pitkäjänteisiä ja erityisiä, mutta kenties "pervoon" kriittisesti suhtatuvat ovat oikeassa siinä, että käsite uusintaa sukupuolen moninaisuuden toissijaistamista myös queer-yhteisön sisällä.

\section{Pervon perintö}

Pervon puolustukseksi voi todeta, että se on kunniakkaasti toiminut osana tutkimusterminologian suomennosprojektia. Esimerkiksi viimeaikaiseen käännösehdotukseen "kvääriin" verrattuna pervo on jo suomen kieleen vakiintunut sana. Pienellä kielialueella on elintärkeää, että tuotetaan ja käytetään omankielisiä käsitteitä. On olennaista, että tutkimuksen "lingua francaksi" hyväksytty englanti ei saavuta täysin umpi-imperialistista asemaa, vaan tutkijat pystyvät edelleen kommunikoimaan omasta työstään, myös sukupuolen ja seksuaalisuuden kriittisestä tutkimuksesta, äidinkielisesti (Rossi 2019).

On myös oleellista hahmottaa, että käsite ei ole vain yksittäinen sana vaan merkityksellistämisjärjestelmä, joka kantaa mukanaan vahvasti paikantuneita elementtejä. Yhdysvaltalainen valtavirtapopuläri- ja somekulttuuri eivät ole todellisuuden lingua franca, eikä vieraskielinen tutkimuskäsitteistö pysty tavoittamaan samaa kumousvoimaa kuin paikalliset, omakieliset vastineet. Osin tämä johtuu siitä, että vieraskieliset käsitteet eivät tunnu yhtä vereslihaisilta - toisaalta yhtä ilkikurisen osuvilta mutteivät myöskään yhtä loukkaavilta - kuin ilmaukset kielellä, johon meillä on myös ensisijainen tunneside (ks. esim. Toivo \& Scheepers 2019; Mizielinska 2006). Juuri siksi" queer" on helpompi affektiivisesti hyväksyä kuin "pervo". Mutta tekeekö helppous hallaa kumouksellisuudelle? Vaikka pervo ehkä - "liian" outona ja kierona? - on poistumassa suomenkielisen queer-tutkimuksen parrasvaloista, pervotutkimuksen perintö elää. Pervon paluu on mahdollinen, koska "perverssin seksuaalisuuden määrittelyssä on kiinnostavinta se, ettei se ankkuroidu loppujen lopuksi mihinkään, vaan sen merkitys pysyy kontingenttina”. (Kekki 2006, 7.) Toivoisimme tämän perinnön kumouksellisen voimavaran säilyvän ja tulevan kestävämmin sovelletuksi myös sukupuolen moninaisuuden tutkimuskysymyksissä.

\section{Kirjallisuus}

Aldrin Salskov, Salla, Riikka Taavetti \& Leena-Maija Rossi. 2019. Paikantumisia queer-tutkimuksen käsitteisiin ja historiaan. SQS 1-2/2019, I-IV. DOI: https://doi.org/10.23980/sqs.89152

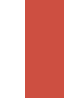


Drescher, Jack. 2010. Queer Diagnoses: Parallels and Contrasts in the History of Homosexuality, Gender Variance, and the Diagnostic and Statistical Manual. Archives of Sexual Behavior 39(2), 427-460.

Juvonen, Tuula. 1993. Kurittomat kokemukset: queer studies lesbotutkimuksen haasteena. Tiede ja edistys 18(4), 277-283.

Kekki, Lasse. 2006. Pervon puolustus. Kulttuurintutkimus 3/2006, 3-18.

Kekki, Lasse. 2010. Pervo parrasvaloissa. Queer-draamaa Texasista Kokkolaan. Toim. Pia Livia Hekanaho \& Jarmo Haapanen. Turku: Eetos.

Lahti, Annukka, Kia Aarnio, Anna Moring \& Jenni Kerppola. 2020. Perhe- ja läheissuhteet sateenkaaren alla. Helsinki: Gaudeamus.

Mizielinska, Joanna. 2006. Queering Moominland: The Problems of Translating Queer Theory into a Non-American Context. SQS 1/2006, 87-104. https:// journal.fi/sqs/article/view/53722

Parhi, Katariina \& Sudenkaarne, Tiia. 2020. Sukupuolen ja seksuaalisuuden lääketieteellisiä tulkintoja: Queer-bioetiikka ja haavoittuvuuden kerrokset historiallisissa psykiatrisissa potilaskertomuksissa. Niin\&Näin 2: $145-$ 153.

Rossi, Leena-Maija. 2019. Tutkimuskirjoittamisen (kieli)politiikkaa. Sukupuolentutkimus - Genusforskning 4/2019, 38-41.

Toivo, Wilhelmiina \& Christoph Scheepers. 2019. Pupillary response to affective words in bilingiuals' first versus second language. PLoS ONE 14(4): e0210450. https://doi.org/10.1371/journal.pone.0210450

Vänskä, Annamari. 2006. Vikuroivia vilkaisuja: Ruumis, sukupuoli, seksuaalisuus ja visuaalisen kulttuurin tutkimus. Helsinki: Taidehistorian seura. 